IJOLTL, Vol. 3, No. 2, May 2018

p ISSN: 2502 2326; e ISSN: 2502 8278

Http://ijolt1.pusatbahasa.or.id; Email: ijolt1@gmail.com

Center of Language and Culture Studies, Surakarta, Indonesia

Saleh, Rosana Emy. 2018. Designing Computer Assisted Language Learning

Software Evaluation. IJOLTL (2018), 3(1): 159 166. DOI: 10.30957/ijoltl.v3i2.454.

\title{
DESIGNING COMPUTER ASSISTED LANGUAGE LEARNING SOFTWARE EVALUATION
}

\author{
Emy Rosana Saleh \\ University of Kutai Kartanegara \\ Tenggarong, Kutai Kartanegara, East Kalimantan
}

\begin{abstract}
The use of computer to assist learning has increased significantly through more than three decades. However, the use of the instrument is still becoming a problem among teachers and educators. This paper discusses the evaluation criteria in selecting Computer Assisted Language Learning (CALL) software in language and skill development for ESL/EFL. The CALL evaluation criteria proposed in this paper is aimed to assist English language teachers to determine good quality CALL software used in classroom activity. CALL has proven its benefits for three aspects: programming consideration, educational design, and easy for use. A checklist describing evaluation aspects of the CALL is provided in this paper.
\end{abstract}

Key-words: CALL, computer, design, classroom activity.

\section{DOI: 10.30957/ijoltl.v3i2.454.}

\section{INTRODUCTION}

The use of computer to assist language learning (CALL) has increased significantly through more than three decades (Kotter, 2002). CALL is defined by Levy (1997) as "the search for and study of application of the computer in language teaching and learning" can be used as a creative instrument, as reference, and as a communication tool for teachers and students (Hubbard, 1996).

However, the use of CALL is still becoming a problem among the teachers and educators due to the poor quality of its software (Kotter, 2002; Maddux et.al., 1992). As Gare (1982) points out that the teachers who wish to capitalize on the potential of computer have difficulty in obtaining suitable software to use in their classrooms. She also adds, although the supply of software increased, Maddux (1992) claims there are over 20000 educational computer software available today, the problem is not easily solved. It is mostly because much of this software has been produced by programmers who are not programmers.

Given to this situation, Knowles (1992) suggests that software for language learners needs to be particularly well designed and carefully selected because language learners do 
IJOLTL, Vol. 3, No. 2, May 2018

p ISSN: 2502 2326; e ISSN: 2502 8278

Http://ijoltl.pusatbahasa.or.id; Email: ijolt1@gmail.com

Center of Language and Culture Studies, Surakarta, Indonesia

Saleh, Rosana Emy. 2018. Designing Computer Assisted Language Learning

Software Evaluation. IJOLTL (2018), 3(1): 159 166. DOI: 10.30957/ijoltl.v3i2.454.

not have the same range of language skills and lexis as native speakers. Gare (1982) also adds, the software, which mostly fits into the classroom, not only posses specific subject area of knowledge, but also displays a desired subject methodology. Obviously, the use of poor quality software will only frustrate and confuse such students (Knowles, 1992).

In order to select good quality software that can be applied in a classroom, such a CALL evaluation criteria is required. Gayeski (1993) states, evaluation can serve a variety of different roles or functions, including analyzing needs, refining goals and objectives, documenting activities, improving programs and products, assessing effectiveness and impact, and estimating cost effectiveness. In addition to this, Scholfield (2000) says, evaluation implies an activity where something is declared suitable or not and consequent are to be made or action taken. Evaluating something therefore is not the same as researching it, though research may be done to find out things, which then inform the value judgment and hopefully make it better.

This paper aims to discuss the evaluation criteria in selecting CALL software program for the use of ESL/EFL context.

\section{CALL EVALUATION CRITERIA}

This paper outlines three major criteria, which assist teachers to select a good and an effective CALL software program and teaching purposes, namely; programming consideration, educational design, and ease of use of the program. The general aspects of these criteria will be discussed and particular components are provided in the criteria checklist form.

\section{Programming Consideration}

There are two important aspects included in programming consideration, i.e. description of the program and system requirements.

In general, the previous aspect includes the details of program, name, author, publisher, date of publication, copyright and the program information. As Knowles (1992) states, the record of these details can be helpful to ascertain if the person who published the software is a programmer or a language teacher, or both. The price of software program is also put into consideration. According to Bradin (1992), the most expensive software is not always the best because some of the most successful software can be obtained at low cost or as freeware or shareware. Obviously, the cost of buying software should be reasonable for the value received (Knowles, 1992).

Secondly, the system requirements related to the type of cimputer setting, whether it is stand-alone, intranet, or Internet. These factors determine the need of the server, the Internet access and the hardware requirements. Scholfield (2000) suggests putting a description of detailed aspects of how the program works, with examples of actual items, such as screen, type of computer/platform, etc. since the readers cannot be assumed to be familiar with the software. 
IJOLTL, Vol. 3, No. 2, May 2018

p ISSN: 2502 2326; e ISSN: 2502 8278

Http://ijoltl.pusatbahasa.or.id; Email: ijolt1@gmail.com

Center of Language and Culture Studies, Surakarta, Indonesia

Saleh, Rosana Emy. 2018. Designing Computer Assisted Language Learning

Software Evaluation. IJOLTL (2018), 3(1): 159 166. DOI: 10.30957/ijoltl.v3i2.454.

\section{Educational Design}

Educational design is primarily focused on the objectives of the program and all the pedagogical aspects including language-learning activities, model of tasks, learning style and also feedback for students.

In regard to the objectives of the software, Scholfields (2000) suggests to provide a full account target learners at a particular level, etc. Also, Hubbard (1992) emphasizes that the objectives of the software should be clearly defined.

Furthermore, the other aspects such as language activities: writing, reading, speaking, listening, vocabulary, grammar, pronunciation practices and the tasks; simulation, problem solving, drill and practice, etc. should be present in the software, so that "the learner's needs for language development are fostered " (Knowles, 1992).

Next, learning style has considerable relevance to how teacher and program operate together to create a learning environment for students. It includes neutral, descriptive, investigate, competitive, cooperative, diagnostic and informative learning (Gare, 1982).

Finally, the aspect of learning progress report as feedback for students determines the degree of interactivity between the computer and learners (Steven, 1989). It becomes an important factor not only for the teacher but also for the students, that it can be used to evaluate the teaching learning process in the classroom.

\section{Ease of Use}

Ease of use of software program related to its functionality; the students can use program with minimal teacher help, easy to navigate, and the on screen directions are clear for students. Bradin (1999) claims that the interface (the program's appearance to the user ) should be consistent enough that learners can focus on the task. Furthermore, Knowles (1992) suggests, in order to use the software with ease good instructions are vital - they should be explicit bit not overburdening, the basic operating instructions should be clearly documented and freely available and it should be possible to exit and re-access the program without any difficulty.

\section{CONCLUSION}

The quality of CALL software program is improving but it still becomes a problem due to its poor quality frequently. There are three criteria that should be put into consideration in selecting good and effective software. They involve programming consideration, educational design and ease of use. These aspects are becoming important, since they determine the successful of language learning process in classroom.

\section{REFERENCES}

Bradin, C. 1999. CALL Issues: Instructional Aspects Of Software Evaluation. In Egbert, J. \& Smith, E. H (Ed). CALL Environments; Research, Practice, And Critical Issues. Virginia: TESOL, Inc. 
IJOLTL, Vol. 3, No. 2, May 2018

p ISSN: 2502 2326; e ISSN: 2502 8278

Http://ijoltl.pusatbahasa.or.id; Email: ijolt1@gmail.com

Center of Language and Culture Studies, Surakarta, Indonesia

Saleh, Rosana Emy. 2018. Designing Computer Assisted Language Learning

Software Evaluation. IJOLTL (2018), 3(1): 159 166. DOI: 10.30957/ijoltl.v3i2.454.

Gare, R. 1982. Educational Software Development; A Guide To The Design And The Development of Computer-Based Learning Materials. Queensland: Curriculum Branch, Department Of Education.

Gayeski, D. M. 1993. Multimedia For Learning: Development, Application, Evaluation. New York: Educational Technology Publications, Inc.

Hubbard, P. 1996. Elements Of CALL Methodology: Development, Evaluation, And Implementation. In Pennington, M. C (Ed). The power of CALL. Althestan: Houston, TX

Knowles, S. 1992. Evaluation Of CALL Software: A Checklist Of Criteria For Evaluation. ON-CALL, 6 (2), 9-20.

Kotter, M. 2000. Tandem Learning on the Internet. Germany: Peter Lang GmBh

Levy, M. 1997. Computer-Assisted Language Learning: Context and Contextualization. Oxford: Oxford University Press.

Levy, M. 1998. Evaluation of New Software Packages. In Levy, M. \& Farrugia, D. Computer in Language Teaching: Analysis, Research, And Reviews. Melbourne: TAFE

Maddux, C.D., et. al. 1992. Educational Computing. New York: A division of Simon \& Schuster, Inc.

Scholfield, P. J. 2000. Evaluation of CALL software. Essex, UK. (On-line). Retrieved 8 August 2004 from http://privatewww.essex.ac.uk/-scholp/calleval.htm

Stevens, V. 1989. A Direction for CALL: From Behavioristic to Humanistic Courseware. In m. C. Pennington (Ed.). Teaching Language with Computers. The state of the art. La Jolla, California: Athelstan Publications 
IJOLTL, Vol. 3, No. 2, May 2018

p ISSN: 2502 2326; e ISSN: 2502 8278

Http://ijolt1.pusatbahasa.or.id; Email: ijolt1@gmail.com

Center of Language and Culture Studies, Surakarta, Indonesia

Saleh, Rosana Emy. 2018. Designing Computer Assisted Language Learning

Software Evaluation. IJOLTL (2018), 3(1): 159 166. DOI: 10.30957/ijoltl.v3i2.454.

\section{Appendix: Checklist of Call Software Evaluation}

Instruction: Circle any of these items provided in the second column if you see for "Y N", and give number $(1,2,3,4,5)$ for the blank column. Then, write your description or comments in the third column if it is necessary.

Notes:

$\mathrm{N}=$ no or absent $\quad \mathrm{Y}=$ Yes or available

\begin{tabular}{|c|c|c|}
\hline Rating: & 1 & $=$ very poor \\
\hline & 2 & $=$ poor \\
\hline & 3 & $=$ fair \\
\hline & 4 & $=\operatorname{good}$ \\
\hline & 5 & $=$ very \\
\hline
\end{tabular}

\begin{tabular}{|c|c|c|}
\hline CRITERIA & $\begin{array}{l}\text { Y/N or } \\
\text { Rating }\end{array}$ & Description/Comment \\
\hline 1 & 2 & 3 \\
\hline \multicolumn{3}{|c|}{ I. Programming Consideration } \\
\hline \multicolumn{3}{|l|}{ a. Details of program } \\
\hline Program name & & \\
\hline Author (s) & $\mathrm{N}$ & \\
\hline Publisher & $\mathrm{N}$ & \\
\hline Date of publication & $\mathrm{N}$ & \\
\hline Copyright & $\mathrm{N}$ & \\
\hline Program information & $\mathrm{N}$ & \\
\hline Price & $\mathrm{N}$ & \\
\hline \multicolumn{3}{|l|}{ b. System requirement } \\
\hline \multirow{3}{*}{$\begin{array}{l}\text { Type of computer setting } \\
\text { - Stand alone } \\
\text { Intranet } \\
\text { Internet }\end{array}$} & $\mathrm{N}$ & \\
\hline & Y & \\
\hline & $\bar{Y}$ & \\
\hline \multirow{2}{*}{$\begin{array}{l}\text { Server requirements } \\
\text { - } \quad \text { Type of processor } \\
\text { Type of } \\
\text { computer/platform }\end{array}$} & Y & \\
\hline & $\mathrm{Y}$ & \\
\hline
\end{tabular}


IJOLTL, Vol. 3, No. 2, May 2018

p ISSN: 2502 2326; e ISSN: 2502 8278

Http://ijolt1.pusatbahasa.or.id; Email: ijolt1@gmail.com

Center of Language and Culture Studies, Surakarta, Indonesia

Saleh, Rosana Emy. 2018. Designing Computer Assisted Language Learning

Software Evaluation. IJOLTL (2018), 3(1): 159 166. DOI: 10.30957/ijoltl.v3i2.454.

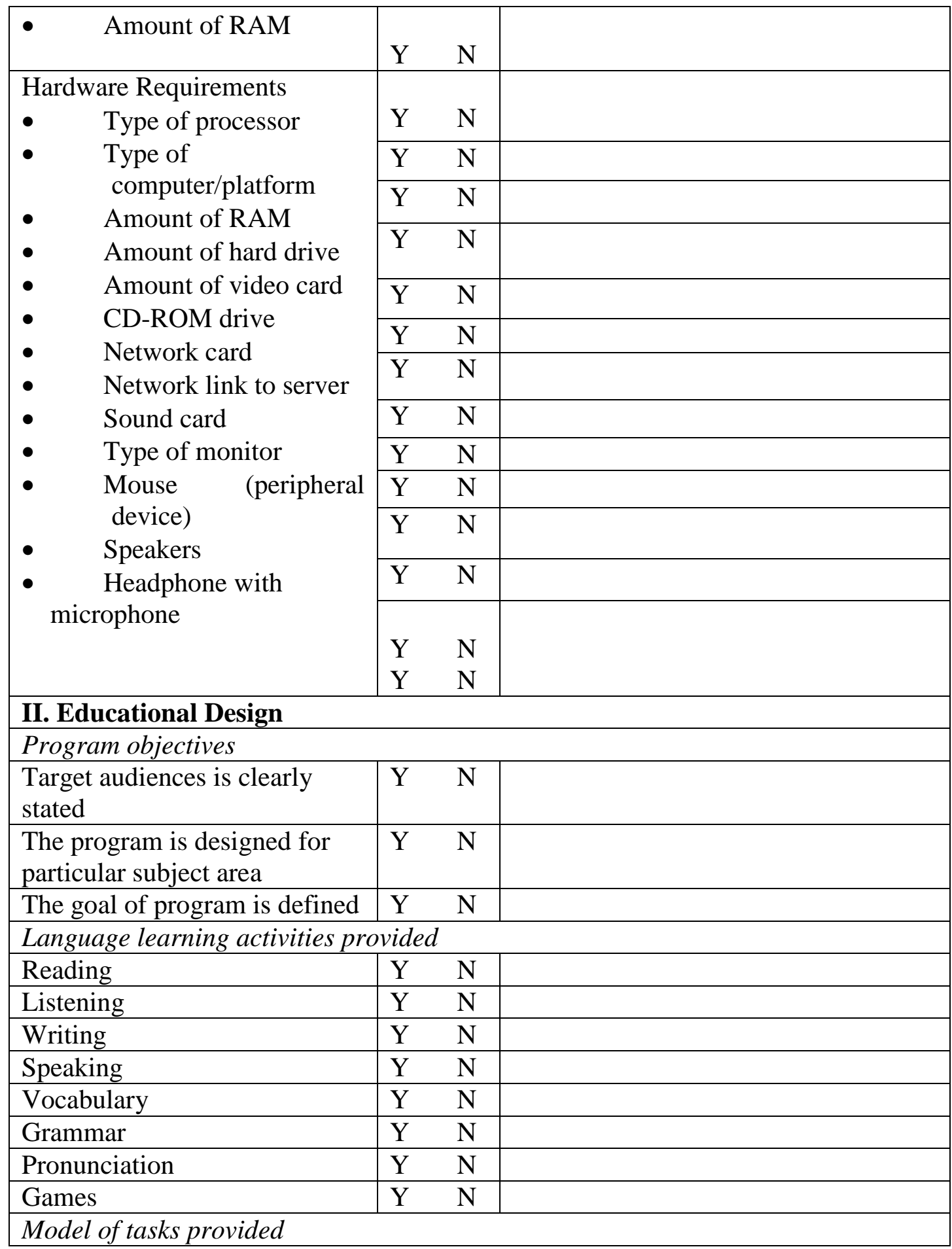


IJOLTL, Vol. 3, No. 2, May 2018

p ISSN: 2502 2326; e ISSN: 2502 8278

Http://ijolt1.pusatbahasa.or.id; Email: ijolt1@gmail.com

Center of Language and Culture Studies, Surakarta, Indonesia

Saleh, Rosana Emy. 2018. Designing Computer Assisted Language Learning Software Evaluation. IJOLTL (2018), 3(1): 159 166. DOI: 10.30957/ijoltl.v3i2.454.

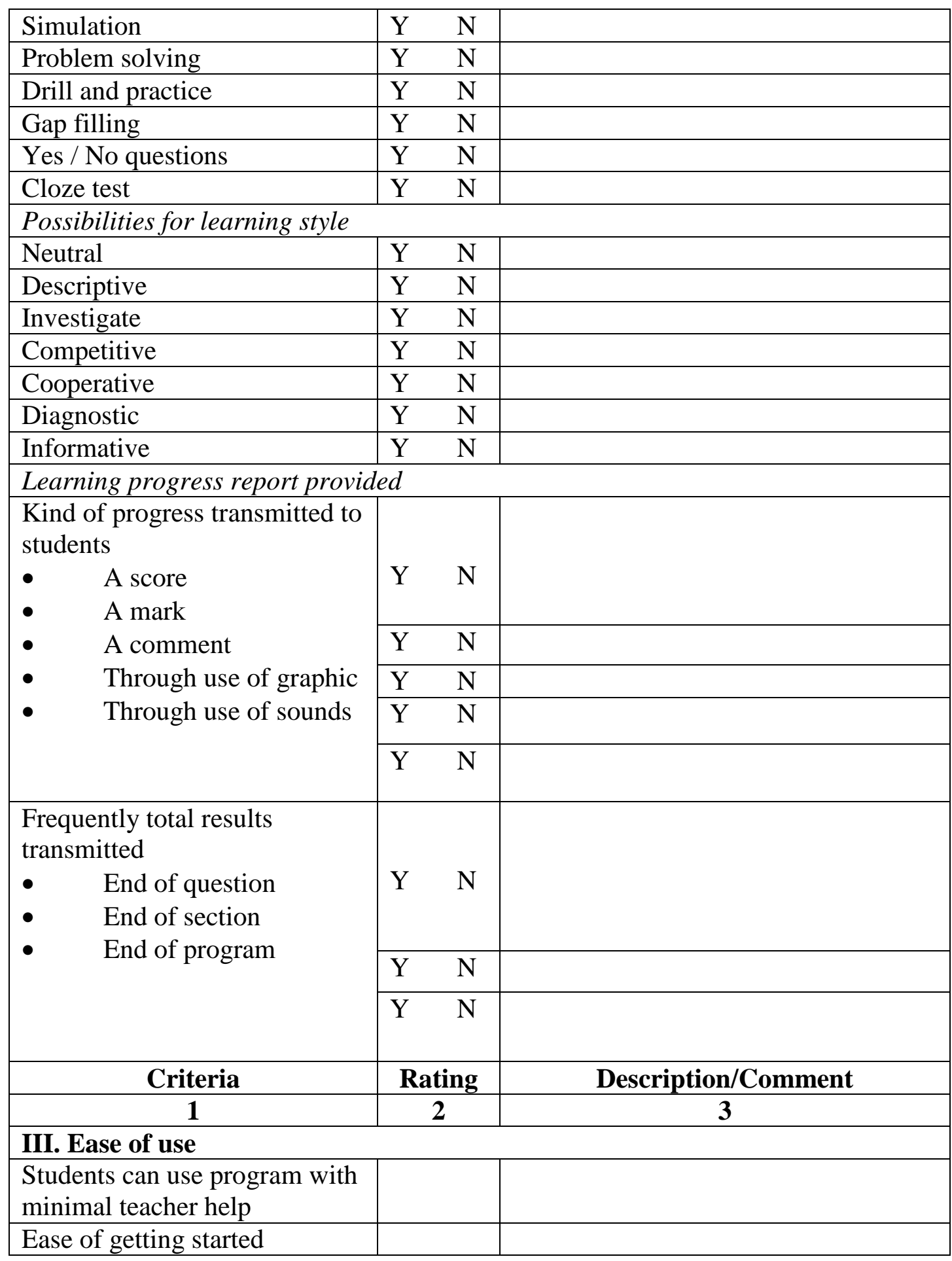


IJOLTL, Vol. 3, No. 2, May 2018

p ISSN: 2502 2326; e ISSN: 2502 8278

Http://ijolt1.pusatbahasa.or.id; Email: ijolt1@gmail.com Center of Language and Culture Studies, Surakarta, Indonesia

Saleh, Rosana Emy. 2018. Designing Computer Assisted Language Learning Software Evaluation. IJOLTL (2018), 3(1): 159 166. DOI: 10.30957/ijoltl.v3i2.454.

\begin{tabular}{|l|l|l|}
\hline $\begin{array}{l}\text { Ease of exit the program at } \\
\text { anytime }\end{array}$ & & \\
\hline $\begin{array}{l}\text { On screen directions are clear, } \\
\text { precise and consistent }\end{array}$ & & \\
\hline $\begin{array}{l}\text { Directions can be skipped at } \\
\text { option of user }\end{array}$ & & \\
\hline $\begin{array}{l}\text { Direction can be reviewed at } \\
\text { anytime }\end{array}$ & & \\
\hline $\begin{array}{l}\text { Background and text work } \\
\text { well together }\end{array}$ & & \\
\hline Students can control sequence & & \\
\hline
\end{tabular}


IJOLTL, Vol. 3, No. 2, May 2018

p ISSN: 2502 2326; e ISSN: 2502 8278

Http://ijoltl.pusatbahasa.or.id; Email: ijolt1@gmail.com Center of Language and Culture Studies, Surakarta, Indonesia

Saleh, Rosana Emy. 2018. Designing Computer Assisted Language Learning Software Evaluation. IJOLTL (2018), 3(1): 159 166. DOI: 10.30957/ijoltl.v3i2.454. 